\title{
Morphometric Studies on the One-Humped Camel Foetus (Camelus dromedarius)
}

\author{
${ }^{1}$ Imam, J., ${ }^{1}$ Hambolu, J.O., ${ }^{1}$ Onyeanusi, B.I., ${ }^{2}$ Ayo, J.O., \\ ${ }^{1}$ Sulaiman, M. H. and ${ }^{1}$ Nzalak, J.O.
}

${ }^{1}$ Department of Veterinary Anatomy, Ahmadu Bello University, Zaria-Nigeria

${ }^{2}$ Department of Veterinary Physiology, Ahmadu Bello University, Zaria-Nigeria

With 3 tables Received September 2017, accepted for publication February 2018

\section{Abstract}

The relationships between the body dimensions, age and weight in the eighty-seven foetuses were determined. Each foetus was weighed and its body dimensions were measured using a string and a measuring tape. The sexes of the foetuses were determined by observing and recording the gonad type in the ventral caudal area. The age of each foetus was determined by measuring the crownrump length. The mean ( \pm SEM) weight of the foetuses ranged from $50.7 \pm 7.4 \mathrm{~g}-14350 \pm 3372 \mathrm{~g}$. The crown-rump length and body length of the foetuses varied from $15.8 \pm 1.2$ $\mathrm{cm}-104 \pm 8.5 \mathrm{~cm}$ and $20.5 \pm 1.7 \mathrm{~cm}$ $-137 \pm 11.7 \mathrm{~cm}$, respectively. The tail length and neck length ranged from $3.3 \pm 0.2 \mathrm{~cm}-24.5 \pm 2.4 \mathrm{~cm}$ and 5.7 $\pm 0.5 \mathrm{~cm}-36.9 \pm 2.6 \mathrm{~cm}$, respectively. The relationships between the mean crown-rump length and body length of the foetuses were highly significant $(P<0.001)$. The mean

J. Vet. Anat. crown-rump length of the foetuses were significant $(P<0.001)$ correlated with age, body weight, body length, tail length and neck length. Body length was significantly $(P<$ 0.001 ) related to age, weight, tail length and neck length. The increase in tail length to neck length occurred at a fairly constant ratio of 1:8.

Keyworda: Morphometric, Camel (Camelus dromedarius), Kano abattoir.

\section{Introduction}

The camel (Camelus dromedarius) belongs to the family, Camelidae. This family is divided into three genera. The old-world camels-(i) genus Camelus the new world camel-(ii) genus Lama and (iii) genus Vicugna (Wilson and Reeder, 2005).

The mean gestation period of the camel is between $315-360$ days (Puschmann, 1989) and May be up 
to $370-375$ days (Fazil and Hofmann, 1981; Arthur, 1992).

The dromedary camel (one-humped camel) is the most important animal to man in the semi-arid areas of Northern and Eastern Africa as well as in the deserts of the Arabian Peninsula. It is a multi-purpose animal, used for its supply of milk, meat, hides and for transport (Schwartz and Dioli, 1992; Farah, 2004; Kane et al., 2005; Kadim et al., 2008).

There is paucity of information on the developmental morphology of organs in the camels, including the lung

This study was conducted to determine the anatomical data of the camel foetus using readily available abattoir specimen.

\section{Materials and Methods}

Study area: The study was carried out in Kano State. It is located in the North-Western part of Nigeria and covers an area of $20,131 \mathrm{~km}^{2}$. Kano State borders Katsina to the northwest, Jigawa State to the north-east, and Bauchi and Kaduna States to the south (Roger, 2009).

Experimental Animals: Eightyseven foetuses were used for the study. They were collected immediately after their dam were slaughtered and the sex of each foetus was recorded.

J. Vet. Anat.
Morphometric Studies: Foetuses were weighed to the nearest $0.1 \mathrm{~g}$ with weighing balance after being carefully dried with a clean towel. The following body dimensions were measured to the nearest $0.1 \mathrm{~cm}$ for each foetus using a string and a measuring tape.

Crowm-rump

length

Body weight

Body length of the foetus

Tail length

Neck length

Foetal Age Estimation: The gestational age of each foetus was estimated using a formula described by Elwishy et al., (1981) as follows: GA $=(C R L+23.99) / 0.366$. Where $G A=$ Gestational age; $\mathrm{CRL}=$ Crown rump length.

Data Analyses: All recorded values were expressed as means \pm standard errors of mean. The statistical package used was Graphpad prism Software, San Diego, California, USA

(WWW.Graphpad.com)

WWW.Graphpad.co).Values of $\mathrm{P}<$ 0.05 were considered significant.

\section{Results}

The age varied from $108.7 \pm 3.3$ days to $349.3 \pm 23.3$ days. The body length ranged from $20.5 \pm 1.7 \mathrm{~cm}$ to $137 \pm 11.7 \mathrm{~cm}$, the crown-rump length ranged from $15.8 \pm 1.2 \mathrm{~cm}$ to 
$104 \pm 8.5 \mathrm{~cm}$ while the weight of the foetuses ranged from $50.7 \pm 7.4 \mathrm{~g}$ to $14350 \pm 3372 \mathrm{~g}$.

The tail length varied from $3.3 \pm 0.2$ $\mathrm{cm}$ to $24.5 \pm 2.4 \mathrm{~cm}$ and the neck length ranged from $5.7 \pm 0.5$ to 36.9 $\pm 2.6 \mathrm{~cm}$. (Table 1). In addition to the increase in age, body length and body weight, regular increase in tail length to neck length was observed at a fairly constant ratio of 1:8 (Table 3).

The crown-rump length and body length were significantly $(P<0.001)$ and directly correlated. The crownrump length of the camel foetus was significantly $(P<0.001)$ and positively correlated with age, body length, body weight, tail length and neck length (Table 2).

\section{Discussion}

The mean crown-rump length of the camel foetus ranging between $15.8 \pm$ $1.2 \mathrm{~cm}$ to $104 \pm 8.5 \mathrm{~cm}$ obtained in this study is less than that of $17.3 \pm$ $0.4 \mathrm{~cm}$ to $116.7 \pm 1.8 \mathrm{~cm}$, reported by Hussein et a., (1991). The mean body length of the camel foetus, which ranged between $20.5 \pm 1.7 \mathrm{~cm}$ to $137 \pm 11.7 \mathrm{~cm}$ in the present study, is less than the range of 22.4 $\pm 0.5 \mathrm{~cm}$ to $154.7 \pm 3.2 \mathrm{~cm}$, reported by Hussein et al. (1991). The body weight of the camel foetus was 48.6 $\pm 4.0 \mathrm{~g}$ to $20933.3 \pm 2547.1 \mathrm{~g}$ and the values were different $(P<0.05)$ from the mean body weight of camel foetus $(50.7 \pm 7.4 \mathrm{~g}$ to $14350 \pm 3372 \mathrm{~g})$ obtained in this study. The differences in the dimension obtained in the present study and that of Hussein et al. (1991) may be due to the variation in size of the animals, environmental condition and nutritional factors (Sivachelvan et al., 1996).

Body measurements steadily increased in the present study with increasing gestational age, and the crown-rump length was highly correlated $(P<0.01)$ with gestational age $(r=0.9546, P<0.001)$.

Therefore, the developmental age may be estimated from foetus crownrump length. In addition, since the correlation obtained between crownrump length and body length was high, body length may also be used to estimate camel foetal age. This finding is in agreement with the findings of Elwishy et al. (1981) and Hussein et al. (1991) who obtained a highly significant correlation between gestational age and body measurements, and showed that the estimation of foetal age is possible with a fair degree of accuracy. Elwishy et al. (1981) suggested equations that were used to estimate the age of the camel foetus in days (X) from a known body dimension.

The result obtained by Hussein et al. (1991) in the one-humped camel showed that the ratio of radius to tibia 
lengths indicates that the rate of the growth of the bones remains constant in relation to one another throughout the period of gestation. However, in this study, in addition to increase in the crown-rump length, body length, age and body weight, regular increase in tail length and neck length were observed at a fairly constant ratio of $1: 8$. The result obtained in the present study demonstrated, for the first time, the relationships between the morphometric parameters of the one-humped camel in the foetus, and that the parameters are directly related. The findings of the present study have demonstrated that the morphometric parameters of the foetus in the camel may be used to determine not only the size of the foetus, but also many morphometric anatomical parameters that are of value in the determination of the age of the foetus, crown-rump length, body length, body weight, tail length and neck length, using the regression equations obtained. Of particular clinical significance is the determination of body weight and age of the foetus using the regression equations generated from the present study. Besides the clinical value of the equations, the data obtained in the present study may be of value in forensic veterinary medicine, involving the determination of some unknown morphometric anatomical data of the foetus, especially the age in the camel.

\section{Conclusion}

Base-line anatomical data of the camel foetus on weight, body length, crown-rump length, tail length and neck length were obtained to the best of our knowledge in Nigeria.

Body weight of camel foetus and other body dimension studied were highly correlated.

\section{References}

Arthur, G.H. (1992): An overview of reproduction in the camelids. Proceedings of $1^{\text {st }}$ International Camel Conference, Dubai, United Arab Emirate, Pp. 109-113.

El-wishy, A.B., Hemeida, N. A., Umar, M. A.,Mobarak, A. M. and Elsayed, M. A. I. (1981): Functional changes in the pregnant camel with special reference to foetal growth. British Veterinary Journal, 137: 527537.

Farah, Z. (2004): An Introduction to the camel. In: Farah, Z. and Fischer, A. (Eds.), Milk and Meat from the Camel - Handbook on Products and Processing. Vdf Hochschulverlag, Zürich, Switzerland, Pp. 15- 28.

FaziL, M.A. and Hofman, R.R. (1981): Haltung und krankheiten des 
Kamels. Tierärztliche Praxis, 9, 389402.

Hussein, F. M., Bahgat, M. N., ElBawab, I. E. and Paccamonti, D. L. (1991): Prenatal Assessment of weight and dimension of the camel conceptus (Camelus dromedarius). Animal Reproduction Science, 25: 129-136.

Kadim, I, T., Mahgoub, O. and Almarzoogi, W. (2008): Meat quality and Composition of longissimus thoracis from Arabian camel (Camelus dromedarius) and Omani beef: A comparative study. Journal of Camelids Sciences, 1: 37-47.

Kane, Y., Kadja, M.C., BadaAlambedji, R., Bezeid, O.E., Akakpo, J.A. and Kaboret, Y, (2005): Lung lesions and bacteria of the one-humped camel (Camelus dromedarius) at Nouakchott slaughter house in Mauritania. Revue d' Elevage et de Medicine Veterinaire de pays Tropicaux, 58(3): 145-150.

Puschmann, W. (1989): Zootierhaltung saugetiere: familie kamele.
VBE Deutscher landwirtschafsverlag, Berlin, Pp. 382-387.

Roger, B. (2009): Traditional livestock breeds: Geographical distribution and dynamics in relation to the ecology of west Africa. Working Paper 122, Produced by Overseas Development Institute, Portland House Stag Place London, SW1E5DP.

Schwartz, H. J. and Dioli, M. (1992): The One-humped Camel (Camelus dromedarius) in Eastern Africa: A Pictorial Guide to Diseases, Health Care and Management. Verlag Josef Markgraf, Weikersheim, Germany. pp. 2-25.

Sivachelvan, M. N., Ghali Ali, M. and Chibuzo, G.A. (1996): Foetal age estimation in sheep and goats. Small Ruminant Research, 19: 6976.

Wilson, D. E. and Reeder, D. M. (2005): Mammal Species of the World ( $3^{\text {rd }}$ Ed.) Smithsonian Institution Press, Washington, USA, 70 pp.

\footnotetext{
${ }^{*}$ Correspondence author:

Dr. Imam, J.

E-mail: jibsimam@gmail.com,jimam@abu.edu.ng and jibsimam@yahoo.com. +2348036194202
} 
Morphometric studies on the dromedary featus

Imam et.al.,

Table (1): Crown-rump, Body Weight, Body Length, Tail Length and Neck Length Length of the Camel Foetus (Mean \pm SEM)

\begin{tabular}{|c|c|c|c|c|c|c|c|}
\hline $\begin{array}{l}\text { Crown- } \\
\text { rump } \\
\text { length } \\
\text { Range }\end{array}$ & $\mathrm{n}$ & $\begin{array}{l}\text { Crown-rump } \\
\text { length }(\mathrm{cm})\end{array}$ & Age (Days) & $\begin{array}{l}\text { Body length } \\
\text { (cm) }\end{array}$ & $\begin{array}{l}\text { Body weight } \\
\text { (g) }\end{array}$ & Tail length $(\mathrm{cm})$ & $\begin{array}{l}\text { Neck } \\
\text { length } \\
\text { (cm) }\end{array}$ \\
\hline $10.5-19$ & 7 & $15.8 \pm 1.2^{\mathrm{a}}$ & $108.7 \pm 3.3$ & $20.5 \pm 1.7$ & $50.7 \pm 7.4$ & $3.3 \pm 0.2$ & $\begin{array}{l}5.7 \pm \\
0.5\end{array}$ \\
\hline $20-25$ & 9 & $23.1 \pm 0.4^{\mathrm{a}}$ & $128.6 \pm 1.1$ & $30.9 \pm 1.1$ & $135.6 \pm 13.3$ & $5.1 \pm 0.2$ & $\begin{array}{l}8.9 \pm \\
0.4\end{array}$ \\
\hline $26-37$ & 29 & $33.6 \pm 0.7^{\mathrm{b}}$ & $157.3 \pm 1.9$ & $43.3 \pm 0.9$ & $425.2 \pm 29.1$ & $7.0 \pm 0.1$ & $\begin{array}{l}12.6 \pm \\
0.4\end{array}$ \\
\hline $38-44$ & 14 & $42.0 \pm 0.6^{c}$ & $251.6 \pm 71.4$ & $54.2 \pm 1.0$ & $766.1 \pm 50.2$ & $9.0 \pm 0.3$ & $\begin{array}{l}16.1 \pm \\
0.3\end{array}$ \\
\hline $45-54$ & 12 & $49.0 \pm 0.9^{d}$ & $199.2 \pm 2.5$ & $64.0 \pm 1.2$ & $1427 \pm 123.9$ & $10.3 \pm 0.3$ & $\begin{array}{l}18.9 \pm \\
0.5\end{array}$ \\
\hline $55-65$ & 5 & $61.9 \pm 1.1^{\mathrm{a}}$ & $234.4 \pm 3.0$ & $81.6 \pm 1.7$ & $2590 \pm 202.1$ & $13.5 \pm 0.7$ & $\begin{array}{l}24.3 \pm \\
1.3\end{array}$ \\
\hline $66-80$ & 5 & $71.1 \pm 2.2^{\mathrm{a}}$ & $259.6 \pm 5.7$ & $93.2 \pm 3.0$ & $4360 \pm 567.3$ & $16.4 \pm 1.1$ & $\begin{array}{l}27.7 \pm \\
1.0\end{array}$ \\
\hline 81-90 & 3 & $83.2 \pm 1.4^{\mathrm{e}}$ & $293.6 \pm 3.6$ & $109.7 \pm 2.0$ & $7283 \pm 683.9$ & $20.5 \pm 0.9$ & $\begin{array}{l}33.1 \pm \\
1.0\end{array}$ \\
\hline $91-125$ & 3 & $104 \pm 8.5^{f}$ & $349.3 \pm 23.3$ & $137 \pm 11.7$ & $14350 \pm 3372$ & $24.5 \pm 2.4$ & $\begin{array}{l}36.9 \pm \\
2.6\end{array}$ \\
\hline
\end{tabular}

$\mathrm{a}, \mathrm{b}, \mathrm{c}, \mathrm{d}, \mathrm{e}$ and $\mathrm{f}=$ Values with different superscript letters within the same column are statistically $(P<0.05)$ significant.

$\mathrm{n}=$ Number of camel foetuses sampled

Table (2): Relationships between Age and Body Dimension of the Foetus of the one-humped Camel (Camelus dromedarius) $(n=87)$

Correlated parameters

Crown-rump length and age

Crown-rump length and body length

Crown-rump length and body weight

Crown-rump length and tail length

Crown-rump length and neck length

Body length and age

Body length and weight

Body length and tail length

Body length and neck length

Body length and crown-rump length
Correlation coefficients
$0.9546^{* * *}$
$0.9999^{* * *}$
$0.9170^{* * *}$
$0.9968^{* * *}$
$0.9948^{* * *}$
$0.9523^{* * *}$
$0.9186^{* * *}$
$0.9971^{* * *}$
$0.9947^{* \star *}$
$0.9999^{* * *}$

$$
{ }^{* * *}=\mathrm{P}<0.001
$$


Morphometric studies on the dromedary featus

Imam et.al.,

Table (3): Length of the Neck and Tail and the Neck:Tail Ratio during the Developmental Stages of One-humped Camel (Camelus dromedarius) Foetus.

\section{Average length}

Range of

Crown-rump

Length (cm)

$10.5-19$

$20-25$

$26-37$

$38-44$

$45-54$

$55-65$

$66-80$

$81-90$

$91-125$

\begin{tabular}{|c|c|c|c|}
\hline & & & $\begin{array}{c}\text { Neck: } \\
\text { Tail }\end{array}$ \\
\hline $\mathbf{N}$ & Neck $(\mathrm{cm})$ & Tail $(\mathrm{cm})$ & Ratio \\
\hline 7 & $5.7 \pm 0.5$ & $3.3 \pm 0.2$ & 1.7 \\
\hline 9 & $5.1 \pm 0.2$ & $8.9 \pm 0.4$ & 1.7 \\
\hline 29 & $7.0 \pm 0.1$ & $12.6 \pm 0.4$ & 1.8 \\
\hline 14 & $9.0 \pm 0.3$ & $16.1 \pm 0.3$ & 1.8 \\
\hline 12 & $10.3 \pm 0.3$ & $18.9 \pm 0.5$ & 1.8 \\
\hline 5 & $13.5 \pm 0.7$ & $24.3 \pm 1.3$ & 1.8 \\
\hline 5 & $16.4 \pm 1.1$ & $27.7 \pm 1.0$ & 1.7 \\
\hline 3 & $20.5 \pm 0.9$ & $33.1 \pm 1.0$ & 1.6 \\
\hline 3 & $24.5 \pm 2.4$ & $36.9 \pm 2.6$ & 1.5 \\
\hline
\end{tabular}




\section{Animal species in this issue}

\section{One-humped came (Camelus dromedaries)}

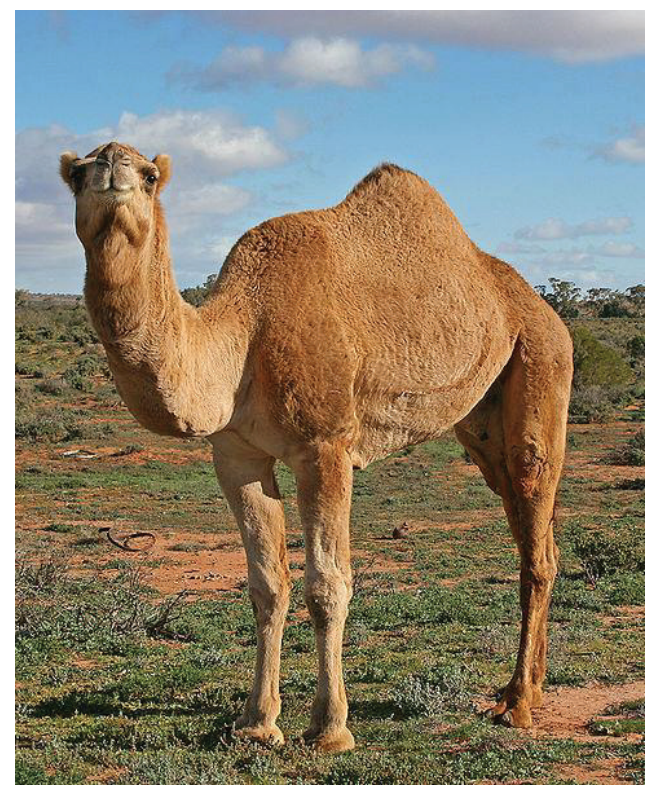

Kingdom: Animalia, Phylum: Chordata, Class: Mammalia, Oder: Artiodactyla. Family:Camelidae, Genus: Camelus

Camel is an even-toed ungulate within the genus Camelus, bearing distinctive fatty deposits known as humps on its back. There are two species of camels: the dromedary or Arabian camel has a single hump, and the Bactrian camel has two humps. They are native to the dry desert areas of West Asia, and Central and East Asia, respectively. Both species are domesticated to provide milk and meat, and as beasts of burden.

The average life expectancy of a camel is 40 to 50 years. A fully grown adult camel stands $1.85 \mathrm{~m}$ at the shoulder and $2.15 \mathrm{~m}$ at the hump. The hump rises about 30 inches $(76.20 \mathrm{~cm})$ out of its body. Camels can run at up to $65 \mathrm{~km} / \mathrm{h}(40 \mathrm{mph})$ in short bursts and sustain speeds of up to $40 \mathrm{~km} / \mathrm{h}(25 \mathrm{mph})$.

Fossil evidence indicates that the ancestors of modern camels evolved in North America during the Palaeogene period, and later spread to most parts of Asia. Humans first domesticated camels before 2000 BC.

Camels are able to withstand changes in body temperature and water content that would kill most other animals. Their temperature ranges from $34{ }^{\circ} \mathrm{C}$ at night and up to $41^{\circ} \mathrm{C}$ during the day, and only above this threshold will they begin to sweat. 